環境システム研究 Vol.22 1994年 8 月

小松・梯川の近自然流路の復元

RESTORING THE NEAR-NATURE SINUOUS CHANNEL OF ARTIFICIALLY

STRAIGHTENED LOWER REACH OF THE KAKEHASHI-RIVER IN KOMATSU

中 川 武夫 ${ }^{*}$
Takeo NAKAGAWA

\begin{abstract}
Based on the experiences of 15 restoration projects in Denmark and Britain, a tentative plan how an artificially straightened lower reach of the Kakehashi-river must be restored by the so-called 'near-nature river construction method', has been proposed. At present, owing to the straightening of the lower reach, the bed is eroded in the upstream, while it is deposited in the downstream. Because the reach is very close to the sea, the deposition of the sediment together with the drift sand due to the waves blocks up the river mouth. Route of the restoring sinuous channel is chosen so as to follow the original one as far as it is possible. Materials and substrata on the bed and banks are, therefore, recovered naturally. The vegetation will be restored by planting grasses, trees or seeds, which are surviving at the neighbouring reaches. The morphological charactristics, to be restored, include the crosssectional shapes, sinuosity, pool and riffles, and point bars. Each of the outside banks will be protected with rip-rap work, and the cross-sectional dimensions will be chosen in such a way that the new channel could flow the expected high-water discharge safely. All of these working processes make the new channel stable. It is suggested that the proposed restoration project solve the blocking-up problem of the Kakehashiriver at the mouth as well as the inner-water drainage problem at the lower reach.
\end{abstract}

KEYWORDS; channel restoration, near-nature river, sediment, vegetation, inner-water drain

1. はじめに

明治 $29(1896)$ 年の河川法成立以来、我国においては連続護岸堤、拡幅、そして蛇行部の直線 化を基本とする河川工法が用いられてきた。ところが、このような工法が川の形態や生態系に対し てのみならず、治水上の観点からも望ましくないことが判明したためにヨーロッパを中心として近 自然な河川流路を復元する試みが近年とみに盛んになってきた。(1)ー(3)ここで、復元されるべき主 たる形態上の特性とは流路断面、蛇行率、淵と瀬、ポィント・バー、底質および粗度である。

古来、柴山潟、今江潟および木場潟を総称したいわゆる加賀三湖は図1に示した「小松殿中写之 からも明らかなように梯川流域に属していた。これらの三湖はいずれも古噴時代の砂丘移動によっ て従来、入江あるいは湾であったところが外海から切り離されることによって湖沼化したものであ って周辺の地勢も極めて平担かつ低湿なものとなっている。(4)

人為的な梯川流路変更のうちで最大なものは明治4 4 (1911) 年1 1月に着手した改修工事であ る。この工事の内容は屈曲の著しい下牧 (石田橋) と鶴ケ島の間を開削し、延長 $4 \mathrm{~km}$ の河道区間を $1.1 \mathrm{~km}$ に每縮し、河口 (安宅) に向けてその河道の直線化をはかったもので大正 12 (1923) 年に 竣工している。(4) しかしながら、その河道の直線化によって梯川河口の土砂堆積による閉塞と梯川 下流域、左岸堤内地の内水問題という新たな問題が派生することとなった。

本論文の主な目的は昭和 58 (1983) 年から昭和62(1987)年の間にデンマークとイギリスの 二つの国で実施された合計１５の近自然河川復元プロジェクトの結果(3)をふまえて、石川県小松市 を貫流する梯川下流域の流路直線化区間の近自然流路への復元案を呈示し、かつその考察を試みる ことである。

2. 梯川流域

梯川の流域図を図 2 に示した。梯川は石川県小松市の鉿ヶ岳（標高１１７４ｍ）に発し山狭を北上し 右から西俣川、郷谷川、光谷川そして泽上川を合わせて中海付近において平野部に出る。平野部に 出てからは左に方向を転じつつ、右から仏大寺川、鍋谷川そして八丁川を合わせたのち小松天満宮

*金沢工業大学 Kanazawa Institute of Technology 


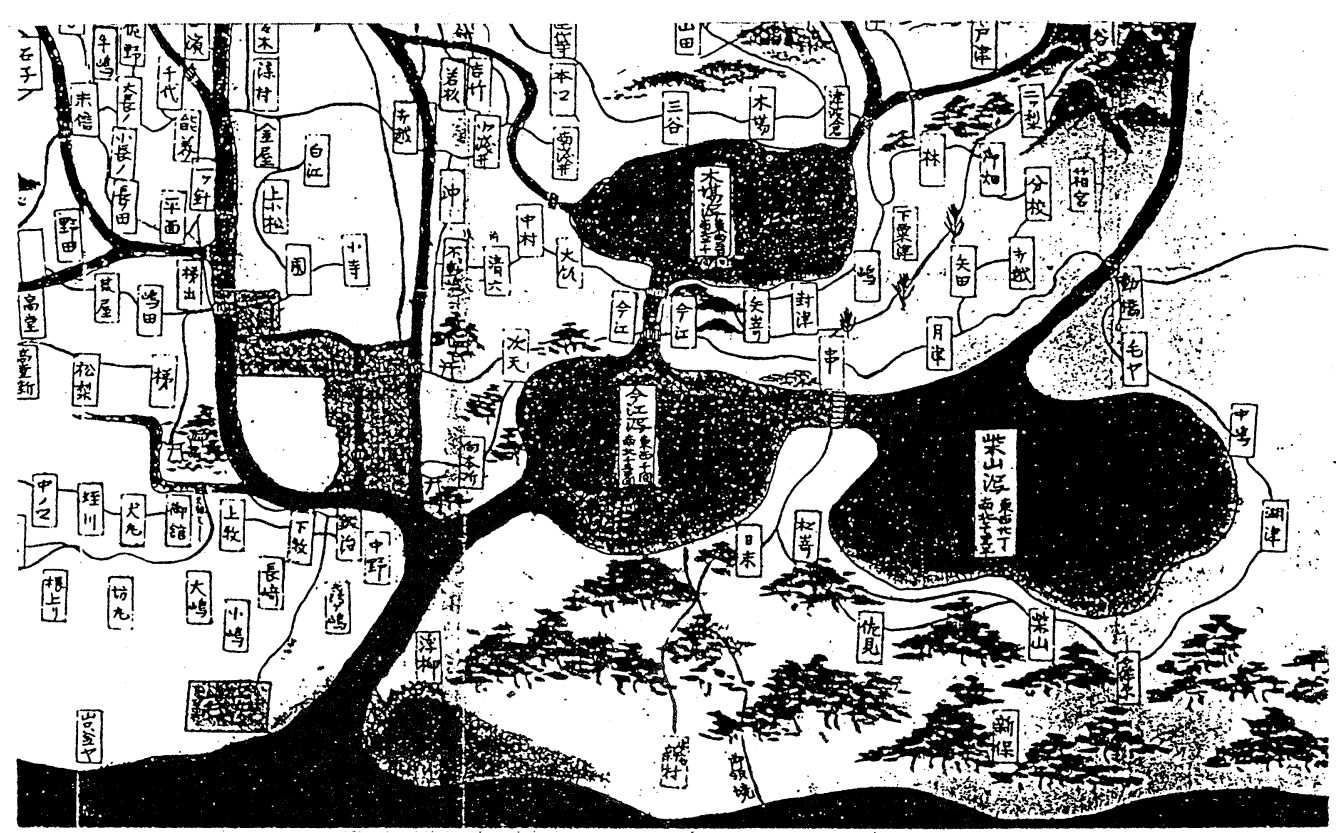

図1. 小松殿中写之「嘉永 4（1８５１）年」の一部（小松市立図書館所蔵）

を右に見ながら小松市街区北部を貫流する。梯川はさらに左から木場潟に発する前川を合わせたのち義経 と开慶の勧進帳で有名な安宅関址を左に見ながら日本海に注ぐ流域面積 $27.1 .2 \mathrm{~km}$ 、流路延長 $42 \mathrm{~km}$ の一級 河川である。

梯川流域は山地が全体の約四分の三を占め、水源地である鉿ケ岳から下流 $12 \mathrm{~km}$ 付近までは急流河川の 態をなすもののそれより下流は典型的な緩流感潮河川となっている。中海と河口との間の最哚河床高の形 状は鍋谷川合流点付近で変曲点をもち、中海と鍋谷川合流点との間の平均河休勾配は 60.0 分の1 程度であ るのに対し、鍋谷川合流点と河口との間の平均河床勾配は 3,500 分の 1 程度と非常に小さくなっている。 梯川下流部における河床の地質は鍋谷川合流点付近で粘土質、八丁川合流点付近で砂磷質そして河口の安 宅付近では砂である。また、鍋谷川合流点より下流の梯川堤内地表層の地質は砂または粘土であるために 流水による侵食を受け易い地盤となっている。このために、梯川は人工の手が加えられる以前の流路は低 湿平野を㮁横無尽に蛇行し、その流路の軌跡は変転極まりない状況であった。(4)

\section{3. 近自然流路復元の段跸}

近自然流路の復元に際して踏むべき7つの段階はデンマークとイギリスにおける合計 15 のプロジェク 卜に基づいて Brookes (3)によって要的されている。ここでは、梯川下流域の近自然流路復元の試案を検 討するために、これらの段階のうち次に掲げる(1)から(3)までに限って考察を加えることとする。

(1)目標の設定：環境上ならびに工学上の目標設定。目標の文書化。

(2)計画の適合性と事前調查 : 水路特性の現状把握とその安定性の評価。復元流路の事前調查による問題点 の明確化。住民並びに土地所有者との協議用として初期許画書の作成

(3)設計 : 図上調査ならびに現流路の断面測定。復元流路の大きさは現流路または隣接流域の河川の自然堤 防区間の状況および現流路に関する古文書、古地因などの歷史資料に基づいて決定。復元流路安定化の ための設計基準の立案（流路の平面ならびに断面形状、堤防の保護法、植裁）。詳細な計画書の作成。

なお、段階(2)の計画の適合性と関連して予定復元流路内の高水時の掃流力が $10 \mathrm{~W} \mathrm{~m}^{-2}$ 加 $35 \mathrm{~W} \mathrm{~m}^{-2}$ の 箐囲にある場合に限って復元後の流路は安定すると報告されているが、ここで対象とする予定復元流路 区間における高水時の掃流力はこの範囲内にあることが確認されている。

4. 梯川の近自然流路復元

図3に梯川下流域、流路直線化区間と予定復元流路の軌跡を示した。明治 44（1911）年に着手し大正 $12\left(\begin{array}{l}1 \\ 9\end{array} 23\right)$ 年に完成した下牧と鶴ヶ島の間の流路直線化工事によりすでに指摘されたように梯川水系に 二つの問影が派生した。第 1 番目には直線化区問の增加した河床勾配により直線化区間より上流において は河床の洗掘が、一方その下流においては河床の堆積が進行したことである。眓 4 に流路直線化区間

(石田橋一北陸高速道路橋) を含む昭和 57 年度の梯川下流部縱断面図を例示した。この圀の横軸は安宅 河口からの流路中心軸の軌跡に沿う距離であり、縦軸は国家水準点である東京湾の平均水位を基準とした 標高を表わしている。この四からも流路の直線化により長年月の間に石田橋と北陸高速道路橋（前川合流 点）との間の河床が洗掘され、一方北陸高速道路橋（前川合流点）より下流の河床には土砂が堆積し河床 


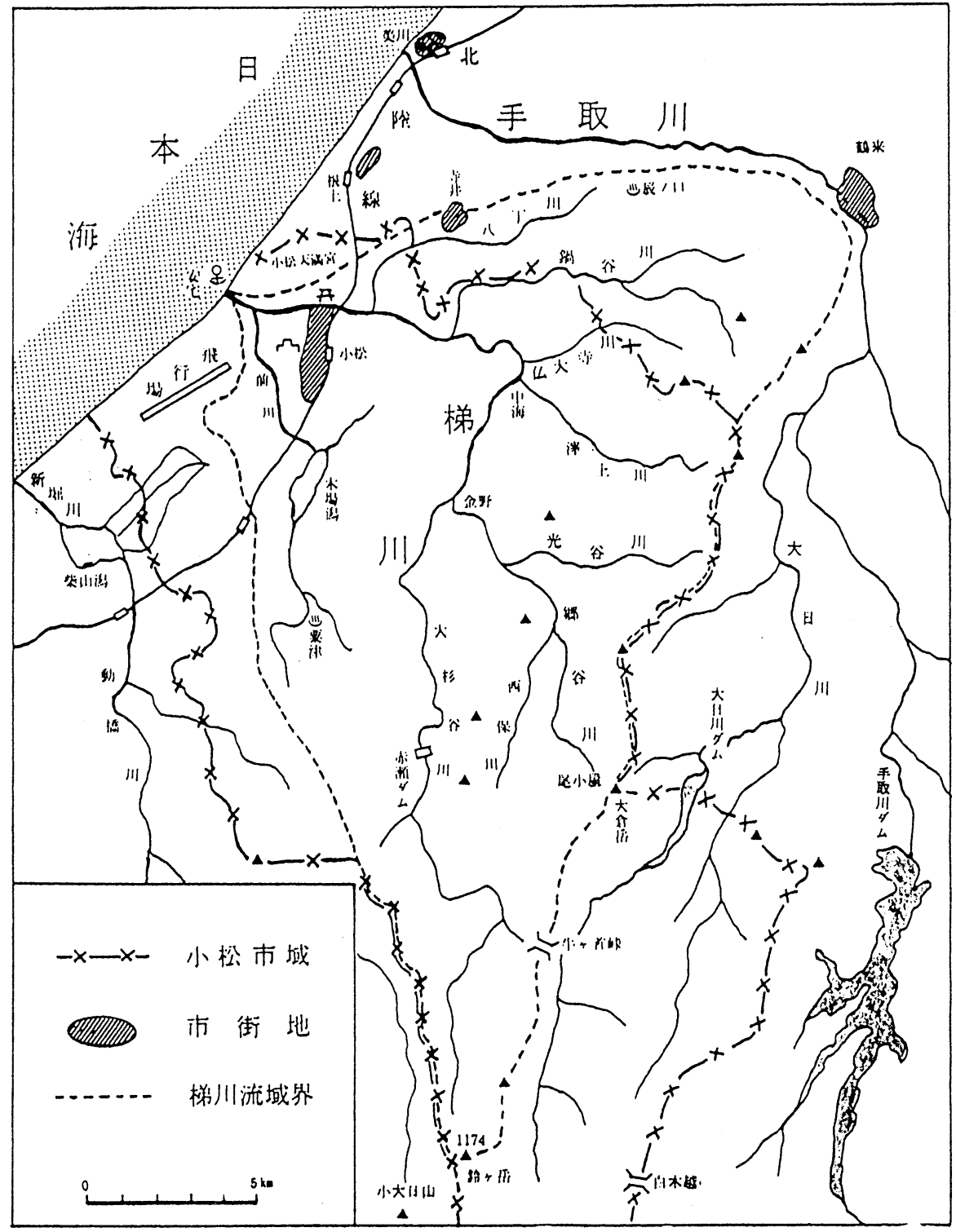

因2. 梯川流域図(小松天満宮と梯川より报すい) 


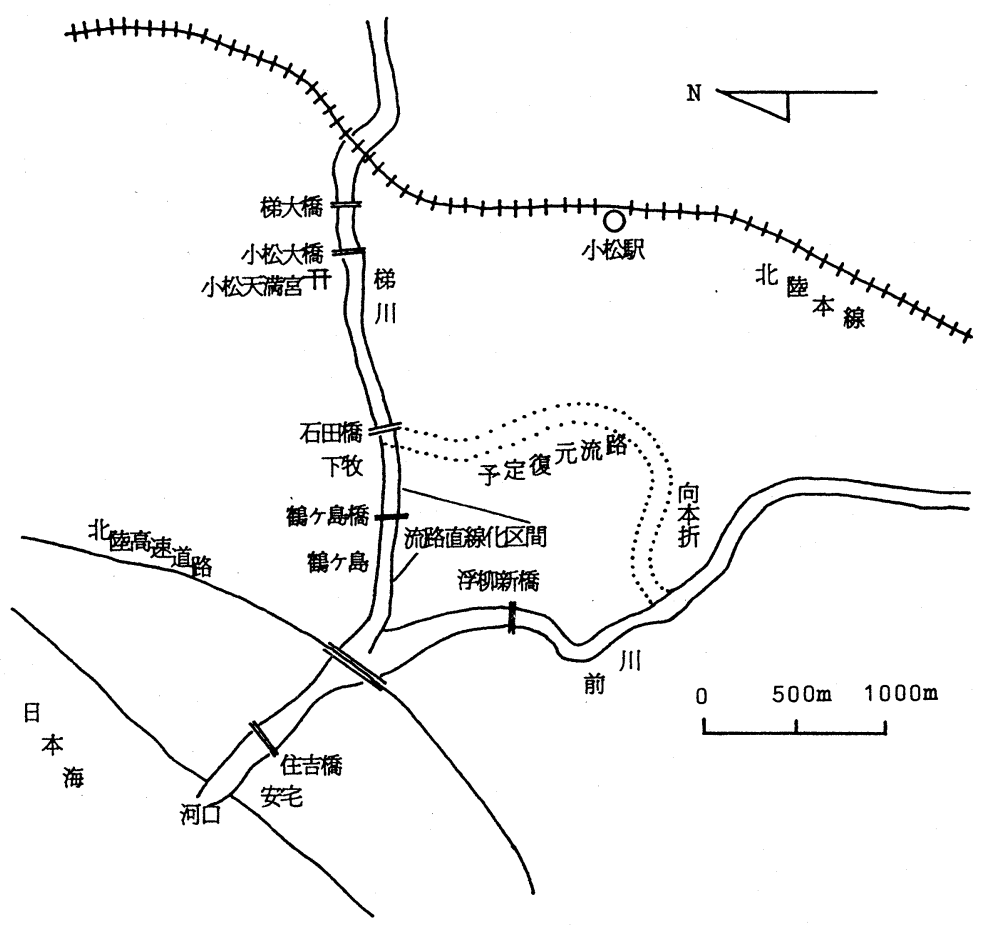

因 3. 梯川下流域、流路直線化区間と予定復元流路

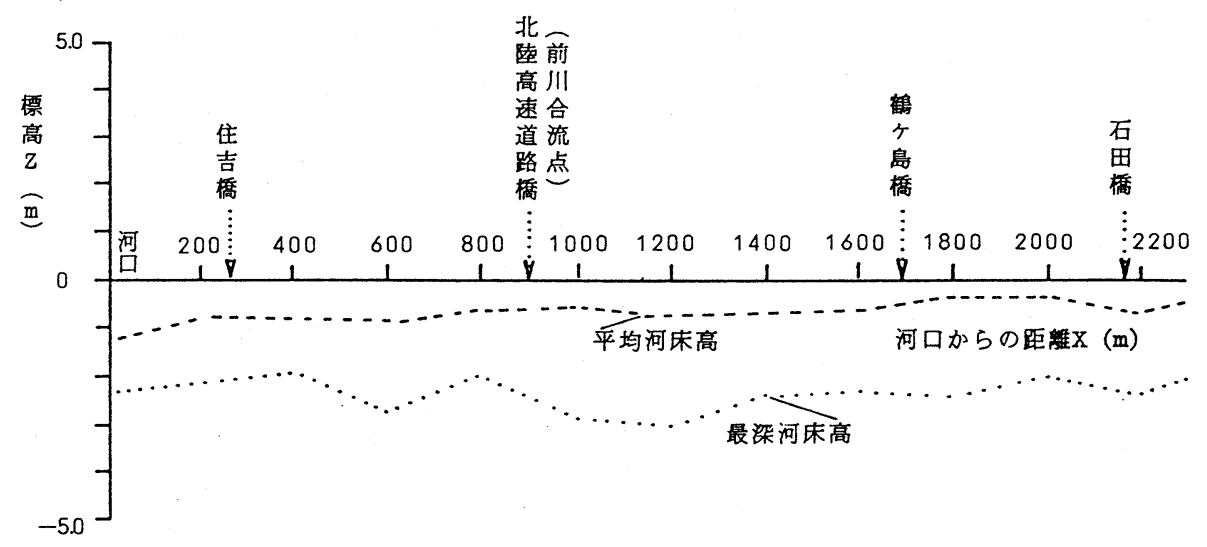

因 4. 梯川下流部縦断面

（昭和 57 年度梯川紸断図建設省金沢工事事務所より抜すい） 
が上昇している状況を理解することができよう。すなわち、安宅河口においては日本海の波や沿岸流によって 河口に運ばれる漂砂に加えて河口に近い下牠 (石田橋)と鶴ヶ島の流路直線化により河床への土砂の堆積が 促進されるので慢性的な閉塞状態にある。このため、安宅河口における漁船等の航行の安全を確保するために定期 的に浚渫を行っているのが実情である。第 2 番目にはここで提案された予定復元流路は図1を参照することによっ て容易に予測することができるように梯川の旧河道の一部にほかならない。すなわち、梯川は下牧（石田 橋）と鶴ヶ島の間が直線化される以前には図了に示した予定復元流路に沿って流れ浮柳新橋の上流の向本 折において前川と合流していた。ところが、現在ではこの予定復元流路に沿って排水路が存在し篤くべき ことにその中の排水が堤内地の平均勾配とは逆方向に前川㑡から梯川に架けられた石田橋に向って非常に ゆっくりと流れている。換言すれば、この排水路の河本勾配は極めて小さいために流れは常に停滞ぎみで あり、その排水能力は著しく低くなっている。わけても、この排水路の流末が梯川左岸堤内地に存在する 排水系統の最下流端に位置する梯川への排水口となっているために、この排水能力の低さが梯川左岸堤内 地全体の内水問題の主因となっている。

図 5 に以上のような問題を解決するために復元すべき流路の平面形状を示した。また、復元流路の河積 は復元流路入口部 (石田橋) における現梯川の通水能力である約 $800 \mathrm{~m}^{3} / \mathrm{s}$ を安全に流しうる程度とする。

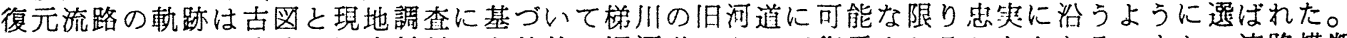

このために、復元流路の河床材料は必然的に旧河道のものが復元されることとなる。また、流路横断面と 平面形状は自然の流路に近いものとなるように定められた。すなわち、A-A $A^{\prime}$ 断面から明らかなように流 路わん曲部の内側にはポイント・バー（寄洲）が形成され河床高は高いが、その外側は淵となるために河 床高は低くなっている。また、流路わん的部外側の流れは収束するために加速されるうえに水面付近にお いてわん曲部の内㑡から外側へ、一方河床付近においては外㑡から内側へ向う二次流の存在によりわん曲 部外側の河床や堤防法面は常に洗掘の危険にさらされることとなる。このために、それぞれの流路わん曲 部外側の河休と堤防法面に捨石工を施し、これらの部分を洗掘より防護することが試みられた。また、二 つの流路わん曲部の中間に位置する B-B' 断面は流路中心軸に対してほぼ左右対称な断面となつている。 この付近は上流わん曲部において収束し加速された流れが拡散する部分であるために流れが隇速し、流送 土砂が堆積する区間である。さらに下流の CーC'断面が位置する流路わん曲部においては流路軌跡は右へ 徐々にその方向を変えている。このために、流路わん曲部内側にポイント・バーが形成され、河床は高い がその外側の河床は低くなっている。また、上流部のわん曲部と同様な理由により、このわん曲部外側の 河休や堤防法面も洗掘からの防護のために捨石工が施されることとなる。このわん曲部より下流において 復元流路はその軌跡をいったん左へわずかに方向を変えたのち向本折において前川に合流する。

もちろん、この新しい梯川一前川合流部から古い梯川一前川合流部までの前川区間は現前川の高水流量 約 $100 \mathrm{~m} / \mathrm{s}$ のみらず、梯川から流入する高水流量䄪 $800 \mathrm{~m} / \mathrm{s}$ を安全に流しうるように流路を拡幅する 必要がある。さらに、復元流路の堤防に沿う堤内地と堤外地において多種の動植物に対して良好な生育環 境を提供するために樹木が植えられるのみならず廃川となる旧流路直線化区間に生育していた植物の移植 やこれらの種子の撒布が行われる。このように流路を復元することにより、梯川は形態学的、生態学的お よび水理学的のいずれの観点からも現状より改善されるはずである。すなわち、形態学的には復元流路は 近自然な蛇行流路となるので改善されることとなる。生態学的にいえば、淵、瀬、ポイント・バーおよび 自然堤防の復元により極めて多様性に富む流れが再生されるために新しい流路によって堤外地はもとより 堤内地の動植物により快適な生育環境が提供されることとなる。また、水理学的にいえば、流路復元によ つてかっての流路直線化が原因で進行しつつある直線化区間上流の洗掘とその下流の堆積が停止し、流送 土砂輸送の平衡状態が実現することとなる。

また、“復元流路は現存する排水路の軌跡に沿いつつ、その内部の水は平均堤内地盤の高い方から低い方 へ自然に流れて前川に合流することとなる。このため、復元流路はその左右堤内地の内水排除にも有効な 役割を果すものと考えられる。

\section{5. おわりに}

川は元来、天からの降水によって大地に刻まれた自然の水路である。この意味からいえば、自然な川は 形態学そして水理学のいずれの観点からも最もバランスのとれたものであって、あらゆる河川改修計画を 立案するにあたつてその基礎を構成するものである。この視点を忘れて三面張連続コンクリート護岸、拡 幅そして蛇行部の直線化、湖沼の埋立などの不自然な河川改修工事を実施すれば短期的または長期的に必 ず対象とする流路にアンバランスが生じ、さまさまな問題が引き起こされることとなろう。本論文におい て取り上げた梯川下流域における下牧 (石田橋) と鶴ヶ島との間の流路直線化工事に伴うて派生した河床 の洗掘と堆積の問題はまさにこの種の典型的な事例の一つであるといえよう。

川はあたかも生きもののような挙動を示す。すなわち、水系内のいかなる河川の現状変更といえども程 度の差はあるとしても水系全体に影響をおよほすすものである。したがって、河川改修工事を実施するにあ たってはこれに伴って対象とする流路に起こることが予想される形態学的、生態学的およひ水理学的変化 を充分に検討することが肝要である。

梯川は周辺に住む人々の天神信仰とも密接な関係にあった。すなわち、梯川の河口、安宅より約 $3 \mathrm{~km} の$ 右岸に小松天満宮が鎮座ましましている。大正時代には天満宮のお祭りになると左岸から対岸の小松天満 宮まで渡し舟が出ていた。当時の子供達は天満書きといって半紙に習字を書いたものを持って渡し舟に乗 り天満宮にこれを奉納したものであるという。このように小松天満宮と梯川は一体となって天神信仰 を広め、人々の生活を豊かで潤いのあるものにしてきたわけである。梯川と融和した小松天满宮の神域は まさにわれわれの心のよりどころであり、未来永劫にわたり継承されていくべき至宝である。 
建設省は今から約 23 年前の昭和 46 (1971)年に同省河川局によって立案された「梯川水系工事実施 基本計画」(6) に沿って依然として梯川の改修を行抢うとしている。この計画はコンクリートを用いた連続 護岸、流路の拡幅そして蛇行部の直線化を基本とする旧来からの改修法をそのまま踏襲したものであって 本論文中において議論された近自然河川工法によって早急に再改修されるべき性質の工事である。しかも もし本計画に沿って梯川を改修すれば国の重要文化財である小松天満宮の移転を余儀なくされるの みならず、その河道沿いに現存している多くの民家、社寺、埋蔵文化財包蔵地等の移転または保存措置 を構ずる必要があるので、その損失と社会的影響は尽大である。これと同時に、本邦の河川としては比較 的質の高い現梯川の水際環境を損なうという久点もある。以上の理由から著者は建設省に対して上で指摘 した諸問題と調和するような近自然河川工法に基づく新たな改修計画を立案し、これを実行に移すことを ここに提案する。

\section{参考文献}

(1) Keller,. E A. 1978 Pools, riffles and Channelization. Environmental

Geology, 3, 246-248.

(2) Nunnally, N. R. and Shields, F. D. 1985 Incorporation of environmental features in flood control projects. Technical Report E-85-3, Environmental and Water Quality Operational Studies, US Army Engineer Waterway Experimental Station, Vicksburg, Mississippi.

(3) Brookes, A. 1990 Restoration and enhancement of engineered river channels: Some European experiences. Regulated Rivers:Research \& Management, 5, 45-56.

(4) 「加賀・小松天満宮と梯川」小松天満宮等専門調查報告書、小松天満宮等専門調查会、 昭和 $61(1986)$ 年 3 月、 $418-439,355-358$.

(5) 中川武夫 1993 清流と共生した小松市の街づくりー 一つの試案の提言一、環境システム研究 21 , $210-214$

（6）「梯川水系工事実施基本計画」建設省河川局 昭和 4 6（1971）年 12 月.

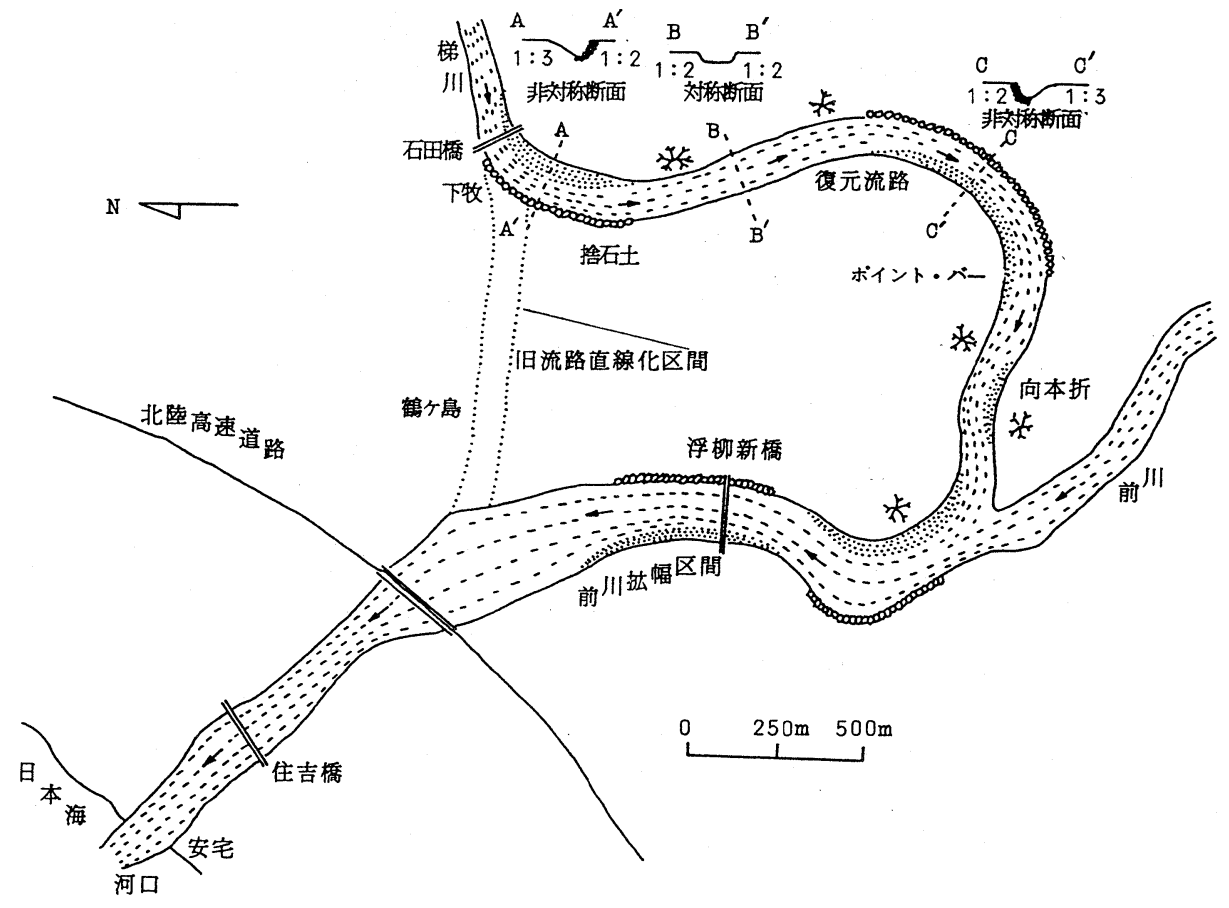

因 5. 梯川下流復元流路 